\title{
Cell growth inhibition and apoptotic effects of a specific anti- RTFscFv antibody on prostate cancer, but not glioblastoma,
} cells [version 1; peer review: 2 approved, 1 approved with reservations]

\author{
Foroogh Nejatollahi (iD1,2, Payam Bayat ${ }^{2}$, Bahareh Moazen ${ }^{1,2}$ \\ ${ }^{1}$ Shiraz HIV/AIDS research center, Institute of Health, Shiraz University of Medical Sciences, Shiraz, Iran \\ ${ }^{2}$ Recombinant Antibody Laboratory, Department of Immunology, Shiraz University of Medical Sciences, Shiraz, Iran
}

V1 First published: 17 Feb 2017, 6:156

https://doi.org/10.12688/f1000research.10803.1

Latest published: 17 Feb 2017, 6:156

https://doi.org/10.12688/f1000research.10803.1

\section{Abstract}

Background: Single chain antibody (scFv) has shown interesting results in cancer immunotargeting approaches, due to its advantages over monoclonal antibodies. Regeneration and tolerance factor (RTF) is one of the most important regulators of extracellular and intracellular $\mathrm{pH}$ in eukaryotic cells. In this study, the inhibitory effects of a specific anti-RTF scFv were investigated and compared between three types of prostate cancer and two types of glioblastoma cells. Methods: A phage antibody display library of scFv was used to select specific scFvs against RTF using panning process. The reactivity of a selected scFv was assessed by phage ELISA. The anti-proliferative and apoptotic effects of the antibody on prostate cancer (PC-3, Du-145 and LNCaP) and glioblastoma (U-87 MG and A-172) cell lines were investigated by MTT and Annexin V/PI assays. Results: A specific ScFV with frequency $35 \%$ was selected against RTF epitope. This significantly inhibited the proliferation of the prostate cells after $24 \mathrm{~h}$. The percentages of cell viability (using $1000 \mathrm{scFv} / \mathrm{cell}$ ) were 52, 61 and $73 \%$ for PC-3, Du-145 and LNCaP cells, respectively, compared to untreated cells. The antibody ( $1000 \mathrm{scFv} / \mathrm{cell})$ induced apoptosis at 50 , 40 and $25 \%$ in PC-3, Du-145 and LNCaP cells, respectively. No growth inhibition and apoptotic induction was detected for U-87 and A172 glioblastoma cells. Conclusions: Anti-RTFscFv significantly reduced the proliferation of the prostate cancer cells. The inhibition of cell growth and apoptotic induction effects in PC-3 cells were greater than Du-145 and LNCaP cells. This might be due to higher expression of RTF antigen in PC-3 cells and/or better accessibility of RTF to scFv antibody. The resistance of glioblastoma cells to anti-RTF scFv offers the existence of mechanism(s) that abrogate the inhibitory effect(s) of the antibody to RTF. The results suggest that the selected anti-RTF scFv antibody could be an effective new alternative for prostate cancer

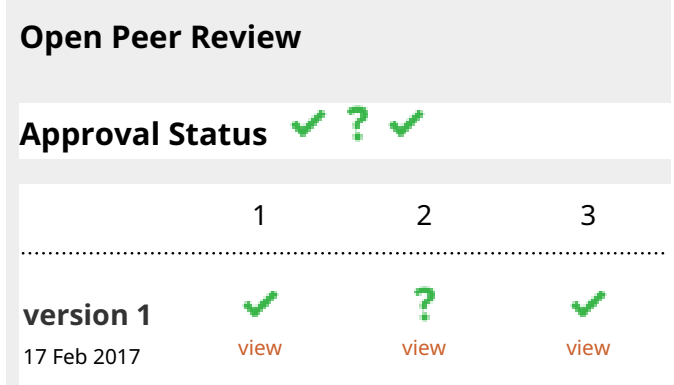

1. Issam Alshami, Taibah University, Medina,

Saudi Arabia

2. Judith Niesen, Fraunhofer Institute for Molecular Biology and Applied Ecology IME, Aachen, Germany

Mira Woitok, Fraunhofer Institute for Molecular Biology and Applied Ecology IME, Aachen, Germany

3. Masoumeh Rajabibazl, Shahid Beheshti University of Medical Sciences, Tehran, Iran

Any reports and responses or comments on the article can be found at the end of the article. 
immunotherapy.

Keywords

Prostate cancer, Anti-RTF scFv, Growth inhibition, Apoptosis, Immunotherapy

Corresponding author: Foroogh Nejatollahi (nejatollaf@sums.ac.ir)

Competing interests: No competing interests were disclosed.

Grant information: This study was financially supported by Shiraz University of Medical Sciences (grant number 90-5538).

The funders had no role in study design, data collection and analysis, decision to publish, or preparation of the manuscript.

Copyright: @ 2017 Nejatollahi F et al. This is an open access article distributed under the terms of the Creative Commons Attribution License, which permits unrestricted use, distribution, and reproduction in any medium, provided the original work is properly cited. Data associated with the article are available under the terms of the Creative Commons Zero "No rights reserved" data waiver (CC0 1.0 Public domain dedication).

How to cite this article: Nejatollahi F, Bayat P and Moazen B. Cell growth inhibition and apoptotic effects of a specific anti-RTFscFv antibody on prostate cancer, but not glioblastoma, cells [version 1; peer review: 2 approved, 1 approved with reservations] F1000Research 2017, 6:156 https://doi.org/10.12688/f1000research.10803.1

First published: 17 Feb 2017, 6:156 https://doi.org/10.12688/f1000research.10803.1 


\section{Introduction}

Prostate cancer is the most prevalent malignancy and the second leading cause of cancer-related death among men in the USA and developing countries ${ }^{1}$. Several new strategies have been employed to manage prostate cancer, including gene therapy, targeted therapy with prodrugs, angiogenesis inhibition and immunotherapy ${ }^{2,3}$. In order to exploit the immune system to retard or even stop tumor cell growth, either via targeting tumor antigens or by disturbing signaling pathways, immunotherapy is a very beneficial method that has been developed ${ }^{4}$. In recent years, monoclonal antibody-based immunotherapy has been used to target prostate-associated antigens ${ }^{5,6}$. Targeting prostate-associated antigens may make conventional therapeutic regimens, including chemotherapy and radiotherapy, more beneficial if applied in combination ${ }^{7}$. To provide an effective targeted therapy, a number of prostate cancerrelated antigens have been used, including prostate-specific antigen (PSA), prostate specific membrane antigen (PSMA), prostatic acid phosphatase, Prostatic stem cell antigen (PSCA) and kalikrein4 (KLK4 $^{8-12}$. Regeneration and tolerance factor (RTF), a novel membrane protein, has also been introduced as a new attractive target for immunotherapy, since its overexpression has been observed in many kinds of malignant and metastatic cancers, and it has been shown to exert immunoregulatory properties ${ }^{13,14}$. RTF is the $\mathrm{a}_{2}$ isoform of $\mathrm{V}_{0}$ subunit, which is one of the vacuolar $\mathrm{H}^{+}$-ATPase (V-ATPase) proton pumps and participates in the control of $\mathrm{pH}$ in normal and tumor cells via proton pumping across the membrane to the extracellular space or intracellular organelles, which, in turn, contributes to extracellular acidification and maintenance of relatively neutral cytosolic $\mathrm{pH}^{15}$. Acidifying the tumor microenvironment plays a key role in tumor cell proliferation, metastasis and resistance to chemotherapy ${ }^{13,14}$. It has been shown that anti-RTF monoclonal antibody can block RTF-ATPase activity and induces apoptosis in a Jurkat $\mathrm{T}$ cell line expressing $\mathrm{RTF}^{16}$. Bermudez et al. ${ }^{17}$ have demonstrated that the RTF molecule is expressed in highly metastatic prostate cancer cells and inhibiting $\mathrm{V}$-ATPase enhances chemosensitivity in metastatic prostate cancer.

Recombinant DNA technology paved the way for the production of recombinant antibody ( $\mathrm{rAb})$ fragments, such as single-chain variable fragment $(\mathrm{scFv})$ antibodies, which are composed of variable heavy $\left(\mathrm{V}_{\mathrm{H}}\right)$ and light $\left(\mathrm{V}_{\mathrm{L}}\right)$ chains linked by a flexible peptide linker ${ }^{18-21}$. Properties of scFv antibodies, including smaller molecular size, human origin and better penetration to the target compared with whole antibodies, make these molecules suitable for therapeutic applications ${ }^{22-24}$. In the present study, the inhibitory effects of selected anti-RTF scFvs on three prostate cancer cell lines, PC-3, Du-145 and LNCaP cells, and two glioblastoma cell lines, U-87 MG and A-172, were investigated.

\section{Methods}

Selection of anti-RTF scFv antibody

A phage antibody display library of $\mathrm{scFv}$ was developed as described previously ${ }^{18,19}$. Briefly, panning process was performed to enrich the phage library. The RTF peptide amino acids 488510 was employed as the target antigen. The peptide was diluted $(10 \mu \mathrm{g} / \mathrm{ml})$ and coated in a polystyrene immunotube (Nunc, Finland). After an overnight incubation, washing was performed with PBS and blocking solution (10\% FCS [Sigma, UK] and 2\% skimmed milk in PBS) was added to the tube and was incubated at $37^{\circ} \mathrm{C}$ for $2 \mathrm{~h}$. After washing four times with PBS/Tween (PBST) and four times with PBS, phage supernatant diluted with blocking solution (1:1) was added and incubated at room temperature for $1 \mathrm{~h}$. The tube was washed, logarithmic phase TG1 E. coli (Sigma, UK) was added and incubated at $37^{\circ} \mathrm{C}$ for $1 \mathrm{~h}$. The pellet was obtained with centrifugation at $3000 \mathrm{rpm}$ for $5 \mathrm{~min}$, resuspended in $200 \mu \mathrm{l}$ of 2TY broth and plated onto 2TYG Agar/Ampicilin plate and incubated at $30^{\circ} \mathrm{C}$ overnight. Panning process was performed for four rounds to obtain specific scFv antibodies against the desired peptide. The $\mathrm{V}_{\mathrm{H}}$-Linker- $\mathrm{V}_{\mathrm{L}}$ inserts of selected scFv clones were PCR amplified (denaturation $1 \mathrm{~min}$, annealing $1 \mathrm{~min}$, elongation $2 \mathrm{~min}$; $\mathrm{R} 1$ and R2 vector primers). Mva1 fingerprinting (Sigma, UK) was performed on 20 colonies of the panned library to determine the homogenicity and frequency of positive samples of PCR products.

\section{Phage ELISA}

The RTF peptide was diluted to $100 \mu \mathrm{g} / \mathrm{ml}$ and coated in 96 wells polystyrene plate (Nunc, Denmark). The plate was incubated at $4^{\circ} \mathrm{C}$ overnight. The wells containing no peptide, unrelated peptide, M13KO7 helper phage (New England Biolabs, UK) and unrelated $\mathrm{scFv}$ ( $\mathrm{scFv}$ against HER2 ${ }^{21}$ ) were also considered as controls. All the wells were in triplicate. The wells were washed three times with PBST and three times with PBS. A $150 \mu$ l of $2 \%$ skimmed milk were added to each well as blocking solution, and incubation was performed at $37^{\circ} \mathrm{C}$ for $2 \mathrm{~h}$. The wells were washed and diluted phage $\left(10^{9} \mathrm{PFU} / \mathrm{ml}\right)$ was added to each well. M13KO7 was also added to the wells allocated for helper phage instead of phage antibody. The plate was incubated at room temperature for $2 \mathrm{~h}$. Nonbinding phages were removed by washing with PBST and PBS, and diluted anti-Fd rabbit antibody (1/100; catalog no., B7786; Sigma, UK $)^{19}$ was added to each well and incubated at room temperature for $1.5 \mathrm{~h}$. Following washing, peroxidase conjugated goat anti-rabbit IgG (1/4000; catalog no., A0545; Sigma) ${ }^{19}$ was added to each well and incubated at room temperature for $1 \mathrm{~h}$. Nonbinding antibodies were removed by washing and $0.5 \mathrm{mg} / \mathrm{ml}$ of ABTS (Sigma, USA) in citrate buffer $/ \mathrm{H}_{2} \mathrm{O}_{2}$ was added. The optical density of each well was read at $405 \mathrm{~nm}$.

\section{Cell culture}

Human prostate cancer cell lines, PC-3, Du-145 and LNCaP, and human glioblastoma cell lines, U-87 MGand A-172, were purchased from National Cell Bank of Iran, Pasteur Institute of Iran (Tehran, Iran). The cells were cultured and maintained in RPMI 1640 (Biosera, UK) in $\mathrm{CO}_{2}$ incubator at $37^{\circ} \mathrm{C}$. The medium was supplemented with $10 \%$ FBS (Biosera, UK), 100U/ml penicillin and $100 \mu \mathrm{g} / \mathrm{ml}$ streptomycin.

\section{Cell proliferation assay}

Each cell line was transferred into a 96-well flat-bottomed plate $\left(10^{4}\right.$ cells per well) and incubated at $37^{\circ} \mathrm{C}$ overnight. The cells were treated in triplicate with different concentrations of anti-RTF scFv antibodies (100, 200, 500, $1000 \mathrm{scFv} / \mathrm{cell}) ; \mathrm{M} 13 \mathrm{KO} 7$ and 2TY broth media were used as negative controls. After a $24 \mathrm{~h}$ treatment at $37^{\circ} \mathrm{C}$, MTT [3-(4, 5-dimethylthiazol-2, 5-diphenyltetrazolium bromide, $0.5 \mathrm{mg} / \mathrm{ml}$; Sigma, Germany] was added to each well and incubated at $37^{\circ} \mathrm{C}$ for $4 \mathrm{hrs}$. The supernatant was removed and the crystal products were dissolved by adding DMSO (Merck, 
Germany) and incubation at room temperature overnight. Colorimetric evaluation was performed at $490 \mathrm{~nm}$. The percentage of cell growth was calculated from the absorbance value of untreated and treated cells as follows: percentage of cell growth $=$ $\left(\mathrm{OD}_{490}\right.$ treated $/ \mathrm{OD}_{490}$ untreated $) \times 100$.

\section{Annexin V-FITC assay}

Capability of the selected $\mathrm{scFv}$ in inducing apoptosis in the prostate and glioblastoma cells were investigated by Annexin-V/ propidium iodide (PI) assay. In total, $8 \times 10^{5}$ cells were seeded per culture plate and incubated overnight at $37^{\circ} \mathrm{C}$. The cells were treated with anti-RTF scFv antibody (1000 scFv/cell) for $24 \mathrm{~h}$. Untreated cells were considered as negative control. The cells were harvested using $0.25 \%$ trypsin/EDTA, washed with cold PBS and transferred into flow cytometry tubes followed by adding Annexin V-FITC and PI to the both treated and untreated cells. Preparation was completed by adding incubation buffer (Roche Applied Science, Germany) to each tube. The tubes belonged to the 5 cell lines were read with BD FACSCalibur (Becton Dickinson, Franklin Lakes, NJ, USA) and analyzed by WinMDI 2.5 software.

\section{Statistical analysis}

The data obtained from cell proliferation assays were statistically analyzed by ANOVA test using GraphPad Prism 5 software to compare the means of percentages of cell growth between treated and untreated cells. All data are presented as means \pm standard deviation (SD). $p$ value $<0.05$ was considered statistically significant.

\section{Results}

Selection of anti-RTF scFv antibody

DNA fingerprinting of the library clones and the selected clones obtained after four rounds of panning are shown in Figure 1. The different patterns of the library clones demonstrated a diverse and heterogeous library. After panning, a predominant pattern with frequency $35 \%$ (lanes 2, 3, 4, 6, 8, 10, and 11) was obtained, which was considered as selected $\mathrm{scFv}$ against RTF for following experiments.

\section{Phage ELISA}

To evaluate the reactivity of the scFv antibody to the RTF peptide, phage ELISA was performed. The anti-RTF scFv antibodies produced positive ELISA and the average OD was 0.441 at 405 $\mathrm{nm}$ (Figure 2). The baseline reading from the wells with no peptide was 0.075. Unrelated peptide, unrelated $\mathrm{scFv}$ and $\mathrm{M} 13 \mathrm{KO} 7$ wells showed an average absorbance of $0.132,0.142$, and 0.136 , respectively.

\section{Dataset 1. Phage ELISA raw data}

http://dx.doi.org/10.5256/f1000research.10803.d151807

\section{Cell proliferation assay}

The percentage of cell viability after a $24 \mathrm{~h}$ treatment with anti-RTF $\mathrm{scFv}$ for prostate cancer cell lines are shown in Figure 3. Three concentrations 200, 500 and $1000 \mathrm{scFv} /$ cell demonstrated significant
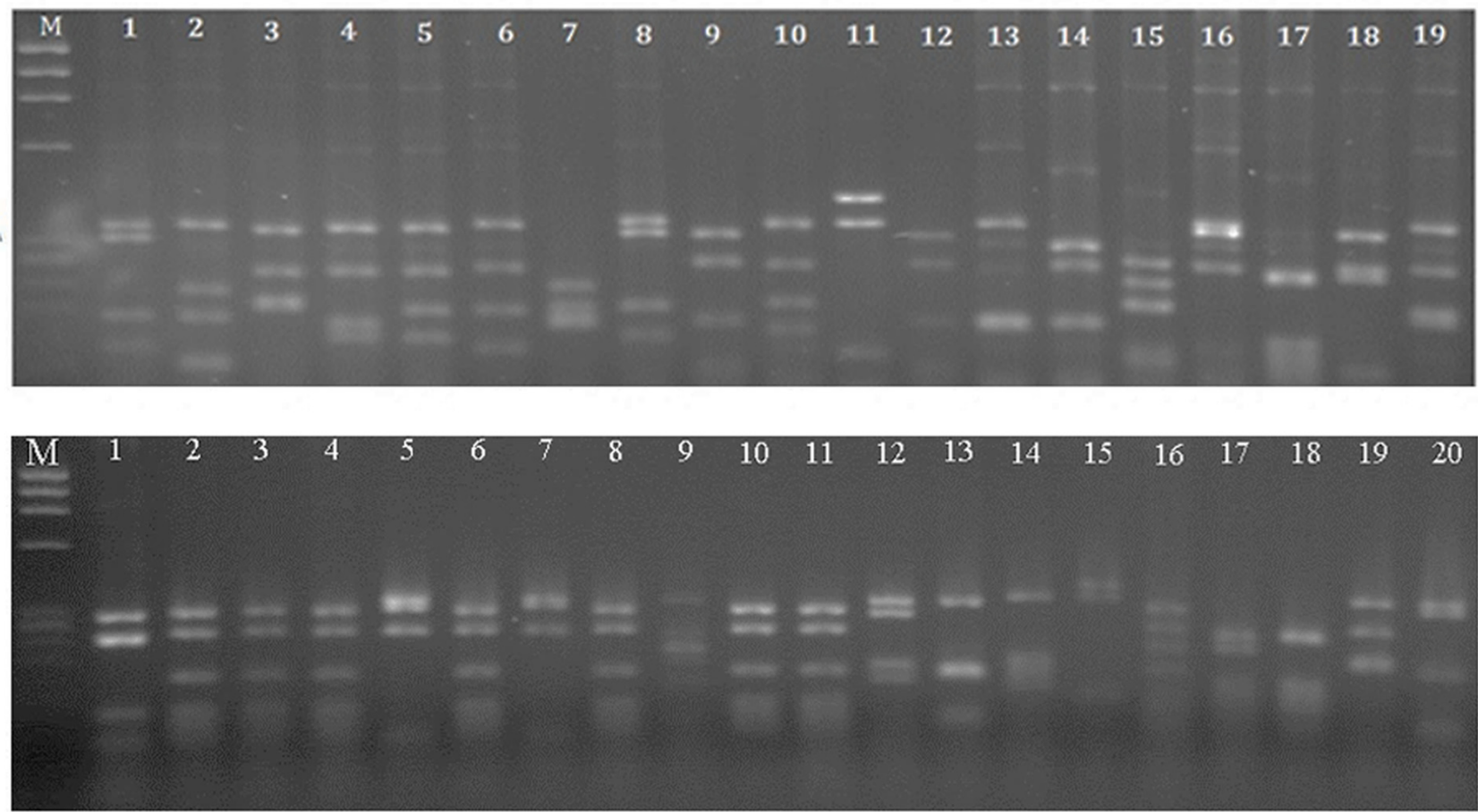

Figure 1. DNA fingerprinting of scFv clones. (A) Heterogeous patterns were obtained for the un-panned library. A common pattern with frequency $35 \%$ (lanes 2, 3, 4, 6, 8, 10 and 11) demonstrated the selection of specific scFv after panning. (B) Marker - øX174 DNA (72-1353 bp). 


\section{Data 1}

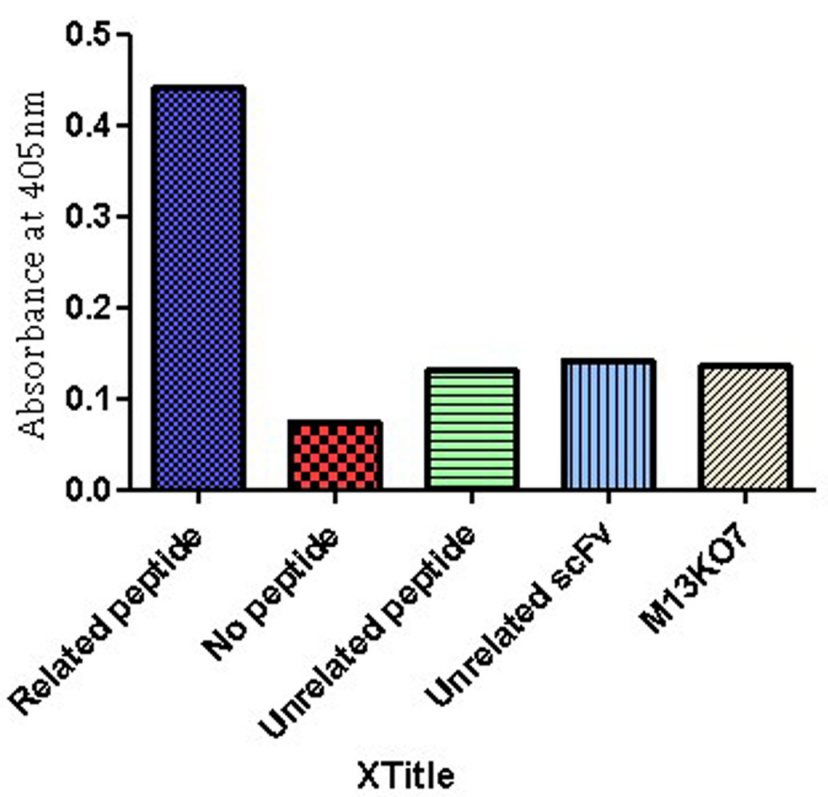

Figure 2. Phage ELISA result of the selected clone. Plates were set in duplicates and wells in tetraplicates.

cell inhibition growth in the three cell lines $(P$ value $<0.05)$. The best growth inhibition was at a concentration of $1000 \mathrm{scFv} / \mathrm{cell}$, and the percentage of cell growth for PC-3, DU-145 and LNCaP cells at these concentrations were 52, 61 and $73 \%$, respectively. No inhibitory effect was observed when the cells were treated with M13KO7 helper phage and 2TY media (negative controls). No significant growth inhibition was detected for glioblastoma cell lines, U-87 MG and A-172 (Figure 4).

Dataset 2. Cell proliferation assay (MTT assay) raw data of three prostate cancer and two glioblastoma cell lines

http://dx.doi.org/10.5256/f1000research.10803.d151808

Apoptosis effects of anti-RTF scFv

Apoptosis was induced in prostate cancer cell lines after a $24 \mathrm{~h}$ treatment with $1000 \mathrm{scFv} /$ cell. In total, 50, 40 and $25 \%$ of PC-3, Du-145 and LNCaP prostate cancer cells, respectively, showed apoptotic cell death (Figure 5), whereas no apoptosis was detected for U-87 MG and A-172 glioblastoma cell lines, representing that the treated cells were viable (Figure 6).

Dataset 3. Apoptosis raw data for three prostate cancer and two glioblastoma cell lines

http://dx.doi.org/10.5256/f1000research.10803.d15180
A
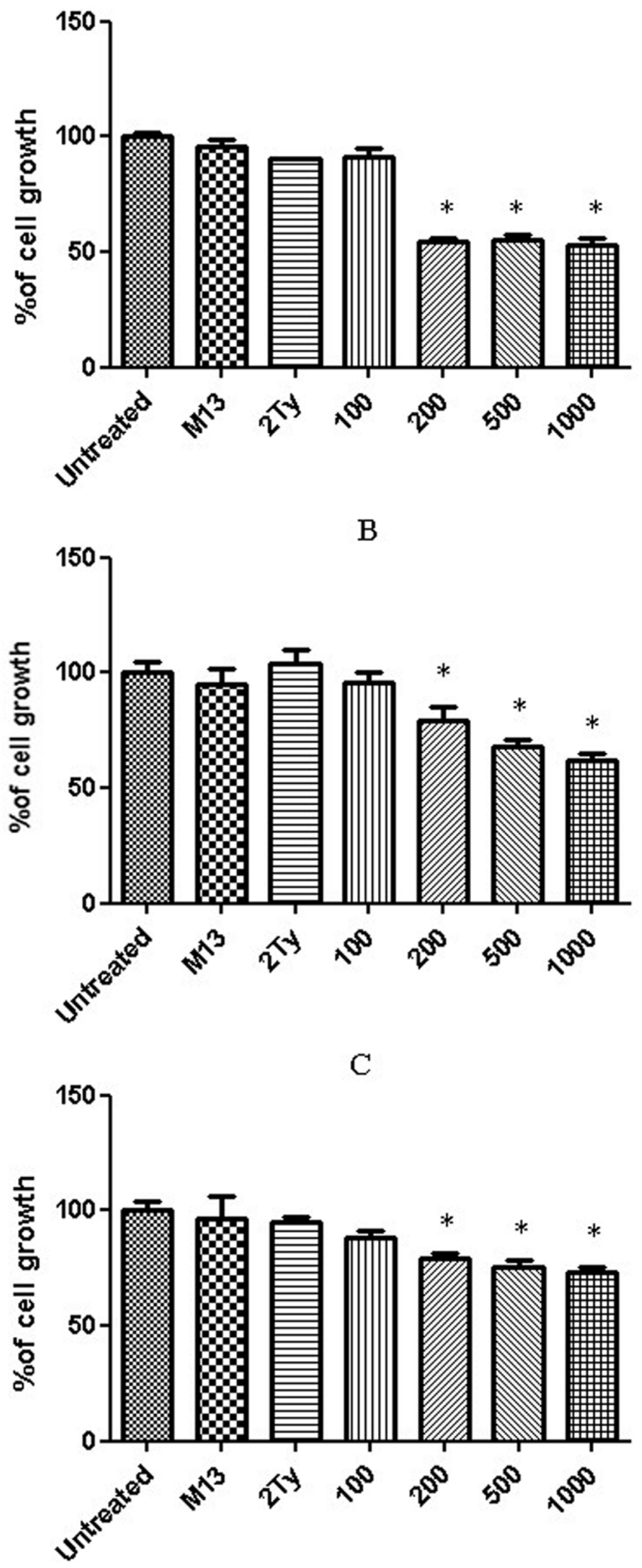

Figure 3. Percentage of prostate cell growth after treatment with anti-RTF scFv. Growth percentage of (A) PC-3, (B) DU-145 and (C) LNCaP cell lines after $24 \mathrm{~h}$ treatment with 100, 200, 500 and 1000 anti-RTF scFv/cell. Results of six experiments; ${ }^{*} P$ value $<0.05$. 

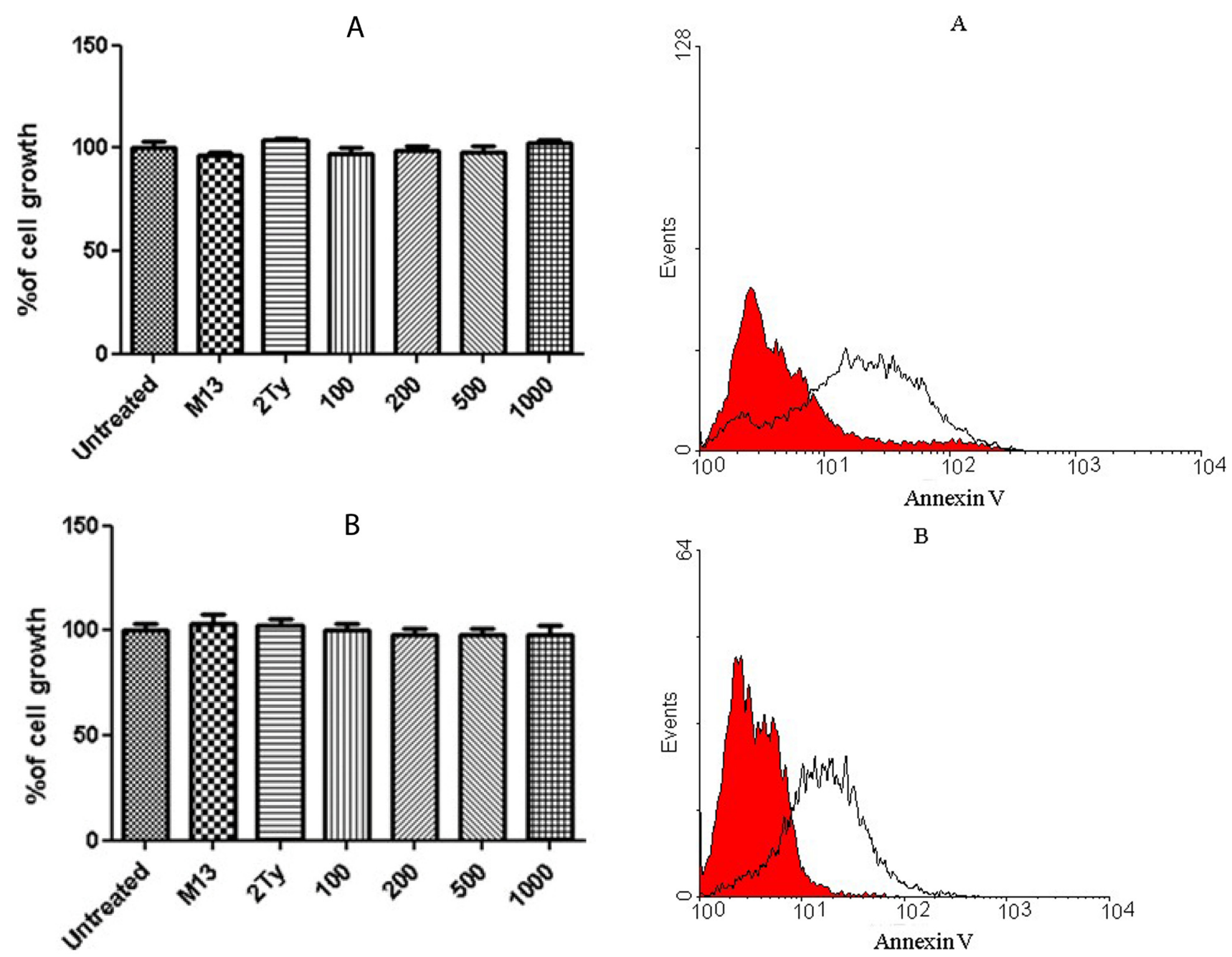

Figure 4. Percentage of glioblastoma cell growth after treatment with anti-RTF scFv. Growth percentage of $(\mathbf{A}) \mathrm{U}-87$ and (B) A-172 cell lines after $24 \mathrm{~h}$ treatment with 100, 200, 500 and 1000 anti-RTF scFv/cell. Non-significant growth reduction was observed. Results of six experiments; ${ }^{*} P$ value $<0.05$.

\section{Discussion}

Recombination DNA technology enables the production of human $\mathrm{scFv}$ fragments with desirable properties for tissue penetration; therefore, providing immunotherapeutic reagents for targeted therapy of cancers ${ }^{25,26}$. The potential role of $\mathrm{scFvs}$ in targeted therapy of melanoma, lung, breast, colorectal and prostate cancers have been shown previously ${ }^{25,27-30}$. To isolate a functional scFv, an identified cell target should be selected ${ }^{31}$. Due to RTF function, which regulates $\mathrm{pH}$ in tumor milieu, it has been considered as an ideal target for cancer immunotherapy, and an anti-RTF monoclonal antibody has been capable of inducing apoptosis in an ovarian carcinoma cell line ${ }^{13}$.

In the present study, we applied $\mathrm{scFv}$ antibodies to target the RTF molecule in both prostate and glioblastoma cancer cells. Amino acids 488-510 of RTF, which was used to isolate anti-RTF

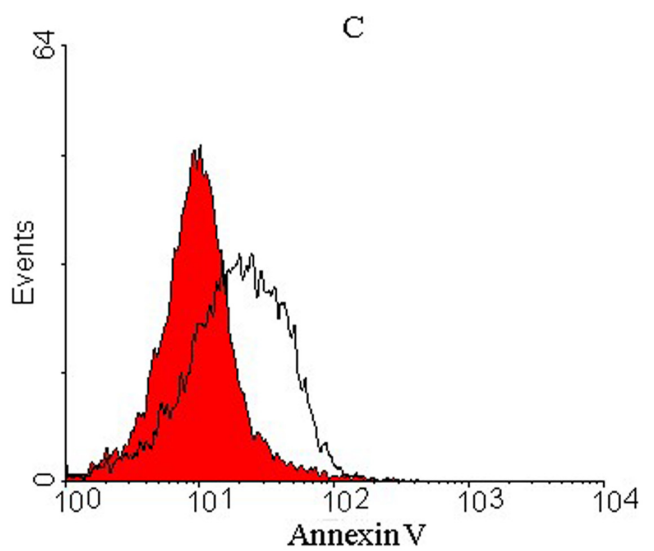

Figure 5. Histograms of untreated and treated prostate cancer cells after $24 \mathrm{~h}$ treatment with anti-RTF scFv/cell. Representative histograms of untreated cells (red) and treated cells (outlined by a black line) after $24 \mathrm{~h}$ incubation period for (A) PC-3, (B) DU-145 and (C) LNCaP prostate cells. A shift in fluorescence intensity observed for the treated cells demonstrated apoptotic cells. Apoptosis occurred in $50 \%$ of PC-3, $40 \%$ of DU- 145 and $25 \%$ of LNCaP cells compared to untreated cells 

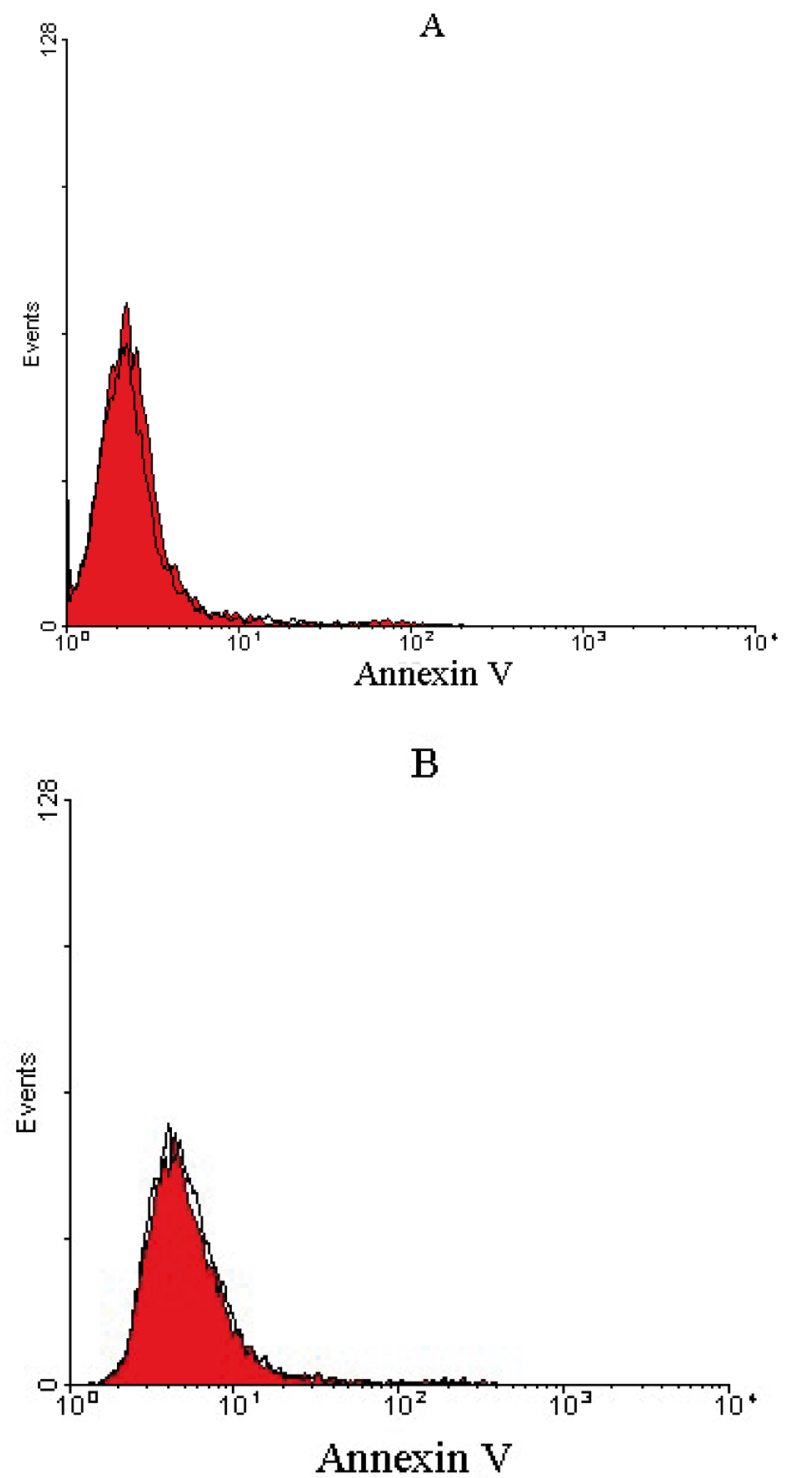

Figure 6. Histograms of untreated and treated glioblastoma cells after $24 \mathrm{~h}$ treatment with anti-RTF scFv/cell. Representative histograms of untreated cells (red) and treated cells (outlined by a black line) after $24 \mathrm{~h}$ incubation period for (A) U-87 MG and (B) A-172 glioblastoma cells. Untreated and treated glioblastoma cells overlapped, representing that the treated cells were viable and non-apoptotic.

monoclonal antibody ${ }^{32}$, was applied to select specific human $\mathrm{scFv}$ against the peptide. Upon isolation of the $\mathrm{scFv}$ antibody against RTF from a large phage display library (RRID: AB_2636849) to evaluate the anti-proliferative and apoptosis effects of the antiRTF scFv antibody, MTT and Annexin V assays were performed. The obtained results demonstrated a significant cell proliferation inhibition after $24 \mathrm{~h}$ treatment with $200-1000 \mathrm{scFv} / \mathrm{cell}$ for the three prostate cancer cell lines compared to untreated cells. A comparison among cell growth of three prostate cancer cell lines revealed that inhibition of cell growth in the PC- 3 cell line was greater than two other cell lines (Du-145 and LNCaP). This might be due to a higher expression of RTF antigen in PC-3 cells and/or better accessibility of RTF to anti-RTF scFv antibody in PC-3 in comparison with Du-145 and LNCaP cell lines. Although Bermudez et al. ${ }^{17}$ demonstrated that the amount of RTF mRNA in PC-3 is higher than in $\mathrm{LNCaP}$ cells, there has been no experiments to compare the levels of RTF mRNA in Du-145 cell line in comparison with PC-3 and LNCaP cell lines. Therefore, the higher growth inhibition in PC-3 after incubation with anti-RTF scFv could be due to higher amounts of RTF molecule in PC-3 than LNCaP.

No proliferation inhibition was detected for glioblastoma cell lines after incubation with different concentrations of the anti-RTF antibody compared with untreated cells, although the expression of RTF on glioblastoma cells has been confirmed ${ }^{33}$. There could be several possible reasons for resistance of these cells to the antiRTF effect. One could be the lack of RTF molecule accessibility to $\mathrm{scFv}$ antibody at the cell surface, due to antigen masking. The effect of masking of human epithermal growth factor receptor2 (ErbB2) via hyaluronan has previously been reported. The findings have demonstrated that masking of trastuzumab-binding epitope by hyaluronan took place in trastuzumab resistant breast cancer cell lines, such as JIMT-1. This masking contributes to the tumor cell escape from receptor-oriented therapy. Antigen masking can happen through overexpression of mucin (MUC) in tumor cells ${ }^{34}$. In a study that was performed to understand the causative mechanism(s) of trastuzumab resistance in breast and some other cancers, it was discovered that MUC4 masks trastuzumab binding epitope of ErbB2, resulting in reduced binding of trastuzumab ${ }^{35}$. Mishim et al. $^{36}$ demonstrated increased expression of podoplanin, which is a mucin-like transmembrane sialoglycoprotein in glioblastoma tumor cells. Therefore, a similar masking mechanism might also be attributed in glioblastoma cells, which precludes RTF binding to anti-RTF scFv antibody. Existence of other isoforms $\left(a_{1}, a_{3}\right.$, and $\left.a_{4}\right)$ of a subunit of proton pump on the cell surface can be considered as another possible mechanism that inhibits the anti-proliferative effects of anti-RTF $\mathrm{scFv}$ antibodies on U-87 MG and A-172 cell lines. In addition, the proton pump is not the only mechanism of $\mathrm{pH}$ regulation in tumor cells. A number of strategies are involved in control and regulation of $\mathrm{pH}$ in glioblastoma cell, such as sodium-proton exchanger-1 (NHE1). It has been demonstrated that U87 MG cell line increases the expression of NHE1 molecule in contrast to normal brain cells to maintain an optimal intracellular $\mathrm{pH}^{37}$. However, the mechanism(s) involved in the non-responsiveness of U87 MG and A172 to anti-RTF scFv antibody remains to be elucidated.

It has been shown that proton pump inhibitors induce apoptosis in human B-cell tumors through a caspase-independent mechanism ${ }^{38}$. The apoptosis-inducing effects of anti-RTF monoclonal antibody on ovarian carcinoma cells was assessed using Annexin V-FITC assay, and the J774A1 macrophage cell line incubated with antiRTF showed a complete inhibition of surface ATPase activity ${ }^{39}$ (US patent, US 7211257 B2). In addition, the role of the anti-RTF in T cell apoptosis has been shown ${ }^{18}$. In the present study, the results of Annexin V-FITC assay were consistent with the MTT assay: apoptosis was induced in the three treated prostate cancer cells, however no evidence of apoptosis was observed in the treated glioblastoma cells. In recent years many efforts have been made to induce apoptosis in tumor cells through antibodies. For example, the anti-Fas monoclonal antibody was produced and exploited for apoptosis 
induction in several glioblastoma cell lines. Although some of glioblastoma cell line, such as LN-18 and LN-215, were sensitive to treatment with the monoclonal antibody against Fas, other cell lines, such as LN-308 and LN-405, showed resistance to anti-Fas antibody-mediated apoptosis. The reason for sensitivity was higher expression of Fas molecule in sensitive rather than in resistant cell lines ${ }^{40}$. Single chain antibodies to some tumor markers, such as PSCA and IL25 receptor, have been capable of triggering apoptosis in tumor cells ${ }^{23,41}$. The lack of accessibility of RTF to scFv antibody and probably the presence of compensatory mechanism to $\mathrm{pH}$ regulation not only can inhibit an anti-proliferative effect, but also can protect the glioblastoma cells from undergoing apoptosis. By comparison, these characteristics were not observed for prostate cancer cells and the novel $\mathrm{scFv}$ selected in this study showed significant anti-cancer effects on the prostate cancer cells.

Due to several advantages of $\mathrm{scFvs}^{42}$, a number of single chain antibodies have been selected against prostate cancer biomarkers, such as PSA, PSMA and PSCA ${ }^{41,43,44}$. Although anti-PSMA scFv has shown promising effects for prostate cancer immunotherapy and has been introduced as a tool for building theranostic reagents for prostate cancer $^{30}$, it originated from a murine monoclonal antibody which induces human anti mouse antibody response (HAMA) ${ }^{45,46}$. Whereas the $\mathrm{scFv}$ selected in this study originated from human immunoglobulin genes and does not elicit any HAMA reaction. In addition, the ability for genetic manipulation can improve the antibody effect to produce fusion proteins with additional effector functions ${ }^{46-49}$. The inhibitory effect of human scFvs against prostate cancer was also reported by Vaday et al. ${ }^{50}$. In that study, two scFvs were selected against CXCR4 and their inhibitory effects on CXCL12- mediated prostate cancer cell activation was investigated. The high affinity scFvs bound to receptor CXCR4 and inhibited its ligand, CXCL12, which resulted in cancer cell inhibition.

The panning process, as used by the present study, in the selection of scFvs against a target that enriches a phage antibody leads to isolation of specific antibodies with high affinity and high specificity. The novel anti-RTF single chain antibodies selected in this study with significant anti-proliferative and apoptotic functions on the three prostate cancer cell lines offers specific antiprostate immunotherapy. Future efforts should be focused on testing the ability of anti-RTF $\mathrm{scFv}$ to inhibit prostate cancer growth in experimental models. Manipulation of the selected anti-RTF scFv and conjugation with a toxin may increase its ability to eliminate tumor cells and contribute to glioblastoma immunotherapy.

\section{Data availability}

Dataset 1: Phage ELISA raw data. doi, 10.5256/f1000research. 10803.d15180751

Dataset 2: Cell proliferation assay (MTT assay) raw data of three prostate cancer and two glioblastoma cell lines. doi, 10.5256/ f1000research.10803.d151808 52

Dataset 3: Apoptosis raw data for three prostate cancer and two glioblastoma cell lines. doi, 10.5256/f1000research.10803. d $151809^{53}$

\section{Author contributions}

Foroogh Nejatollahi participated in the study conception, coordinated and helped to draft the manuscript, Payam Bayat performed data collection, analyzed the data and drafted the manuscript. Bahareh Moazen participated in data collection and interpretation and helped draft the manuscript.

\section{Competing interests}

No competing interests were disclosed.

\section{Grant information}

This study was financially supported by Shiraz University of Medical Sciences (grant number 90-5538).

The funders had no role in study design, data collection and analysis, decision to publish, or preparation of the manuscript.

\section{Acknowledgements}

The present article was extracted from a thesis written by Payam Bayat (unpublished thesis: Selection of human recombinant antibodies against RTF and evaluation of their effects on prostate and glioblastoma cell lines; grant number, 90-5538).
1. Torre LA, Bray F, Sieget RL, et al:: Global cancer statistics, 2012. CA Cancer J Clin. 2015; 65(2): 87-108.

PubMed Abstract | Publisher Full Text

2. Amer $\mathrm{MH}$ : Gene therapy for cancer: present status and future perspective. $\mathrm{Mo}$ Cell Ther. 2014; 2: 27.

PubMed Abstract | Publisher Full Text | Free Full Text

3. Mukherii D, Temraz S, Wehbe D, et al:: Angiogenesis and anti-angiogenic therapy in prostate cancer. Crit Rev Oncol Hematol. 2013; 87(2): 122-31. PubMed Abstract | Publisher Full Text

4. Vieweg J: Immunotherapy for advanced prostate cancer. Rev Urol. 2007; 9(Suppl 1): S29-38.

PubMed Abstract | Free Full Text

5. Westdorp H, Sköld AE, Snijer BA, et al:: Immunotherapy for Prostate Cancer: Lessons from Responses to Tumor-Associated Antigens. Front Immunol. 2014; 5: 191. PubMed Abstract | Publisher Full Text | Free Full Text

6. Neves H, Kwok HF: Recent advances in the field of anti-cancer immunotherapy.
BBA Clin. 2015; 3: 280-288

PubMed Abstract | Publisher Full Text | Free Full Text

7. Rotow J, Gameiro SR, Madan RA, et al: Vaccines as monotherapy and in combination therapy for prostate cancer. Clin Trans/ Sci. 2010; 3(3): 116-122. PubMed Abstract | Publisher Full Text | Free Full Text

8. Kantoff PW, Schuetz TJ, Blumenstein BA, et al.: Overall survival analysis of a phase II randomized controlled trial of a Poxviral-based PSA-targeted immunotherapy in metastatic castration-resistant prostate cancer. J Clin Oncol. 2010; 28(7): 1099-105.

2010; 28(7): 1099-105.
PubMed Abstract | Publisher Full Text | Free Full Text

9. Akhtar NH, Pail O, Saran A, et al.: Prostate-Specific Membrane Antigen-Based Therapeutics. Adv Urol. 2012; 2012: 973820.

PubMed Abstract | Publisher Full Text | Free Full Text

10. Graddis TJ, McMahan CJ, Tamman J, et al.: Prostatic acid phosphatase expression in human tissues. Int J Clin Exp Pathol. 2011; 4(3): 295-306. PubMed Abstract | Publisher Full Text | Free Full Text 
11. Karan D, Dubey S, Van Veldhuizen $\mathrm{P}$, et al:: Dual antigen target-based immunotherapy for prostate cancer eliminates the growth of established tumors in mice. Immunotherapy. 2011; 3(6): 735-46.

PubMed Abstract | Publisher Full Text

12. Day CH, Fanger GR, Retter MW, et al.: Characterization of KLK4 expression and detection of KLK4-specific antibody in prostate cancer patient sera. Oncogene. 2002; 21(46): 7114-7120

PubMed Abstract | Publisher Full Text

13. Sennoune SR, Bakunts $\mathrm{K}$, Martínez GM, et al:: Vacuolar $\mathbf{H}^{+}$-ATPase in human breast cancer cells with distinct metastatic potential: distribution and functional activity. Am J Physiol Cell Physiol. 2004; 286(6): C1443-C52. PubMed Abstract | Publisher Full Text

14. Sennoune SR, Luo D, Martínez-Zaguilán R: Plasmalemmal vacuolar-type $\mathbf{H}^{+}-$ ATPase in cancer biology. Cell Biochem Biophys. 2004; 40(2): 185-206. PubMed Abstract | Publisher Full Text

15. Nishi T, Forgac M: The vacuolar $\left(\mathbf{H}^{+}\right)$-ATPases--nature's most versatile proton pumps. Nat Rev Mol Cell Biol. 2002; 3(2): 94-103. PubMed Abstract | Publisher Full Text

16. Boomer JS, Lee GW, Givens TS, et al.: Regeneration and tolerance factor's potential role in T-cell activation and apoptosis. Hum Immunol. 2000; 61(10): 959-71.

PubMed Abstract | Publisher Full Text

17. Bermudez LE: V-ATPase at the Cell Surface in Highly Metastatic Prostate Cancer Cells. Texas Tech University; 2010. Reference Source

18. Nejatollahi F, Hodgetts SJ, Vallely PJ, et al.: Neutralising human recombinant antibodies to human cytomegalovirus glycoproteins $\mathrm{gB}$ and $\mathbf{g H}$. FEMS Immunol Med Microbiol. 2002; 34(3): 237-44. PubMed Abstract | Publisher Full Text

19. Nejatollahi F, Malek-hosseini Z, Mehrabani D: Development of Single Chain Antibodies to P185 Tumor Antigen. Iranian Red Medical Journal. 2008; 10(4): 298-302. Reference Source

20. Cheng $Y$, Li Z, Xi H, et al:: A V -linker-V Orientation Dependent Single Chain Variable Antibody Fragment against Rabies Virus G Protein with Enhanced Neutralizing Potency in vivo. Protein Pept Lett. 2016; 23(1): 24-32. PubMed Abstract | Publisher Full Text

21. Nejatollahi F, Jaberipour M, Asgharpour M: Triple blockade of HER2 by a cocktail of anti-HER2 scFv antibodies induces high antiproliferative effects in breast cancer cells. Tumour Biol. 2014; 35(8): 7887-95. PubMed Abstract | Publisher Full Text

22. Li K, Zettlitz KA, Lipianskaya J, et al.: A fully human scFv phage display library for rapid antibody fragment reformatting. Protein Eng Des Sel. 2015; 28(10): $307-16$.

PubMed Abstract | Publisher Full Text | Free Full Text

23. Younesi V, Nejatollahi F: Induction of anti-proliferative and apoptotic effects by anti-IL-25 receptor single chain antibodies in breast cancer cells. Int Immunopharmacol. 2014; 23(2): 624-32. PubMed Abstract | Publisher Full Tex

24. Nejatollahi F, Asgharpour M, Jaberipour M: Down-regulation of vascular endothelial growth factor expression by anti-Her2/neu single chain antibodies. Med Oncol. 2012; 29(1): 378-83. PubMed Abstract | Publisher Full Text

25. Chames $\mathrm{P}$, Van Regenmortel $\mathrm{M}$, Weiss $\mathrm{E}$, et al:: Therapeutic antibodies: successes, limitations and hopes for the future. Br J Pharmacol. 2009; 157(2): 220-33

PubMed Abstract | Publisher Full Text | Free Full Text

26. Ahmad ZA, Yeap SK, Ali AM, et al.: scFv antibody: principles and clinical application. Clin Dev Immunol. 2012; 2012: 980250. PubMed Abstract | Publisher Full Text | Free Full Text

27. Cianfriglia M, Fiori V, Dominici S, et al:: CEACAM1 is a Privileged Cell Surface Antigen to Design Novel ScFv Mediated-Immunotherapies of Melanoma, Lung Cancer and Other Types of Tumors. Open Pharmacol J. 2012; 6: 1-11. Publisher Full Text

28. Mohammadi M, Nejatollahi F, Ghasemi Y, et al.: Anti-Metastatic and Anti-Invasion Effects of a Specific Anti-MUC18 scFv Antibody on Breast Cancer Cells. App/ Biochem Biotechnol. 2017; 181(1): 379-390.

PubMed Abstract | Publisher Full Text

29. Bremer E: Targeting of the Tumor Necrosis Factor Receptor Superfamily for Cancer Immunotherapy. ISRN Oncol. 2013; 2013: 371854. PubMed Abstract | Publisher Full Text | Free Full Text

30. Frigerio $\mathrm{B}$, Fracasso $\mathrm{G}$, Luison $\mathrm{E}$, et al:: A single-chain fragment against prostate specific membrane antigen as a tool to build theranostic reagents for prostate cancer. Eur J Cancer. 2013; 49(9): 2223-32. PubMed Abstract | Publisher Full Text

31. Ranjbar R, Nejatollahi F, Nedaei Ahmadi AS, et al.: Expression of Vascula Endothelial Growth Factor (VEGF) and Epidermal Growth Factor Recepto (EGFR) in Patients With Serous Ovarian Carcinoma and Their Clinica Significance. Iran J Cancer Prev. 2015; 8(4): e3428. PubMed Abstract | Publisher Full Text | Free Full Text

32. Kulshrestha A, Katara GK, Ibrahim S, et al.: Vacuolar ATPase 'a2' isoform exhibits distinct cell surface accumulation and modulates matrix metalloproteinase activity in ovarian cancer. Oncotarget. 2015; 6(6): 3797-3810. PubMed Abstract | Publisher Full Text | Free Full Text
33. Roth P, Aulwurm S, Gekel I, et al.: Regeneration and tolerance factor: a novel mediator of glioblastoma-associated immunosuppression. Cancer Res. 2006; 66(7): 3852-8.

PubMed Abstract | Publisher Full Text

34. Pályi-Krekk Z, Barok M, Isola J, et al.: Hyaluronan-induced masking of ErbB2 and CD44-enhanced trastuzumab internalisation in trastuzumab resistant breast cancer. Eur J Cancer. 2007; 43(16): 2423-33.

PubMed Abstract | Publisher Full Text

35. Singh AP, Chaturvedi P, Batra SK: Emerging roles of MUC4 in cancer: a novel target for diagnosis and therapy. Cancer Res. 2007; 67(2): 433-6. PubMed Abstract | Publisher Full Text

36. Mishima K, Kato Y, Kaneko MK, et al:: Increased expression of podoplanin in malignant astrocytic tumors as a novel molecular marker of malignant progression. Acta Neuropathol. 2006; 111(5): 483-8.

PubMed Abstract | Publisher Full Text

37. McLean LA, Roscoe J, Jorgensen NK, et al.: Malignant gliomas display altered $\mathrm{pH}$ regulation by NHE1 compared with nontransformed astrocytes. $A m \mathrm{~J}$ Physiol Cell Physiol. 2000; 278(4): C676-C88. PubMed Abstract

38. De Milito A, lessi E, Logozzi M, et al:: Proton pump inhibitors induce apoptosis of human B-cell tumors through a caspase-independent mechanism involving reactive oxygen species. Cancer Res. 2007; 67(11): 5408-17. PubMed Abstract | Publisher Full Text

39. Beaman $\mathrm{K}$ : Methods for inducing apoptosis in ovarian carcinoma cells using an anti-regeneration and tolerance factor antibody. US patent, US 7211257 B2. Reference Source

40. Weller M, Frei K, Groscurth P, et al.: Anti-Fas/APO-1 antibody-mediated apoptosis of cultured human glioma cells. Induction and modulation of sensitivity by cytokines. J Clin Invest. 1994; 94(3): 954-64. PubMed Abstract | Publisher Full Text | Free Full Text

41. Nejatollahi F, Abdi S, Asgharpour M: Antiproliferative and apoptotic effects of a specific antiprostate stem cell single chain antibody on human prostate cancer cells. J Oncol. 2013; 2013: 839831.

PubMed Abstract | Publisher Full Text | Free Full Text

42. Mohammadi M, Nejatollahi F, Sakhteman A, et al.: Insilico analysis of three different tag polypeptides with dual roles in scFv antibodies. $J$ Theor Biol. 2016; 402: 100-6.

PubMed Abstract | Publisher Full Text

43. Parker SA, Diaz IL, Anderson KA, et al:: Design, production, and characterization of a single-chain variable fragment ( $\mathrm{ScFv}$ ) derived from the prostate specific membrane antigen (PSMA) monoclonal antibody J591. Protein Expr Purif. 2013; 89(2): $136-45$

PubMed Abstract | Publisher Full Tex

44. Wang Y, Dossey AM, Froude JW 2nd, et al: PSA fluoroimmunoassays using anti-PSA ScFv and quantum-dot conjugates. Nanomedicine (Lond). 2008; 3(4): 475-83.

PubMed Abstract | Publisher Full Text

45. Nejatollahi F, Silakhori S, Moazen B: Isolation and Evaluation of Specific Human Recombinant Antibodies from a Phage Display Library against HER3 Cancer Signaling Antigen. Middle East J Cancer. 2014; 5(3): 137-44. Reference Source

46. Moazen B, Ebrahimi E, Nejatollahi F: Single Chain Antibodies Against gp55 of Human Cytomegalovirus (HCMV) for Prophylaxis and Treatment of HCMV Infections. Jundishapur J Microbiol. 2016; 9(3): e16241. PubMed Abstract | Publisher Full Text | Free Full Text

47. Mohammadi M, Nejatollahi F: 3D structural modeling of neutralizing SCFV against glycoprotein-D of HSV-1 and evaluation of antigen-antibody interactions by bioinformatic methods. International Journal of Pharma and Bio Sciences. 2014; 5(4): 835-847. Reference Source

48. Nejatollahi F, Ranjbar R, Younesi V, et al:: Deregulation of HER2 downstream signaling in breast cancer cells by a cocktail of anti-HER2 scFvs. Oncol Res. 2013; 20(8): 333-40.

PubMed Abstract | Publisher Full Text

49. Ehsaei B, Nejatollahi F, Mohammadi M: Specific single chain antibodies against a neuronal growth inhibitor receptor, nogo receptor 1: Promising new antibodies for the immunotherapy of Multiple Sclerosis. ShirazE-Med J. 2017; 18(1):e45358. 18(1):e45358.
Publisher Full Text

50. Vaday GG, Hua SB, Peehl DM, et al:: CXCR4 and CXCL12 (SDF-1) in prostate cancer: inhibitory effects of human single chain Fv antibodies. Clin Cancer Res. 2004; 10(16): 5630-9.

PubMed Abstract | Publisher Full Text

51. Nejatollahi F, Bayat $P$, Moazen $B$ : Dataset 1 in : Cell growth inhibition and apoptotic effects of a specific anti-RTFscFv antibody on prostate cancer, but not glioblastoma, cells. F1000Research. 2017. Data Source

52. Nejatollahi $F$, Bayat $P$, Moazen B: Dataset $\mathbf{2}$ in: Cell growth inhibition and apoptotic effects of a specific anti-RTFscFv antibody on prostate cancer, but not glioblastoma, cells. F1000Research. 2017. Data Source

53. Nejatollahi F, Bayat $P$, Moazen B: Dataset 3 in: Cell growth inhibition and apoptotic effects of a specific anti-RTFscFv antibody on prostate cancer, but not glioblastoma, cells. F1000Research. 2017.

Data Source 


\section{Open Peer Review}

\section{Current Peer Review Status:}

\section{Version 1}

Reviewer Report 18 April 2017

https://doi.org/10.5256/f1000research.11649.r20809

(C) 2017 Rajabibazl M. This is an open access peer review report distributed under the terms of the Creative Commons Attribution License, which permits unrestricted use, distribution, and reproduction in any medium, provided the original work is properly cited.

\section{Masoumeh Rajabibazl}

Department of Clinical Biochemistry, Faculty of Medicine, Shahid Beheshti University of Medical Sciences, Tehran, Iran

This is an interesting article and topic. The article is well written.

Research to find new ways to treatment cancer, especially common cancers such as prostate, is valuable. Research on immunotherapy of various cancers with full length antibodies or better than them, antibody fragments such as scFv that have the ability to inhibit the growth of cancer cells is important.

The study is well-designed and good \& valid results have been achieved.

Selection of anti-RTF scFv antibody with anti-proliferative and apoptosis effects against prostate cancer cells is promising. But since scFvs have disadvantages in comparison with whole mAb, in vivo study in future studies is recommended.

It is necessary to impose the following points:

1. It is essential to the results of the phage ELISA be added.

2. Figures 1, 2 and 3 further explanation needed.

Competing Interests: No competing interests were disclosed.

I confirm that I have read this submission and believe that I have an appropriate level of expertise to confirm that it is of an acceptable scientific standard.

Reviewer Report 29 March 2017

https://doi.org/10.5256/f1000research.11649.r21172 
(C) 2017 Niesen J et al. This is an open access peer review report distributed under the terms of the Creative Commons Attribution License, which permits unrestricted use, distribution, and reproduction in any medium, provided the original work is properly cited.

\section{Judith Niesen}

Fraunhofer Institute for Molecular Biology and Applied Ecology IME, Aachen, Germany

\section{Mira Woitok}

Fraunhofer Institute for Molecular Biology and Applied Ecology IME, Aachen, Germany

Nejatollahi et al. presented in their study a novel human scFv fragment against RTF. The manuscript is well written. The results are demonstrated in a detailed and informative way. The manuscript is only ready for indexing after considering the following major and minor comments:

\section{Abstract:}

Beginning: Would be better to say scFvs instead of scFv. Use the plural from.

Methods: library of scFvs instead of scFv; "The anti-proliferative and apoptotic effects of the antibody" please correct to scFv.

Results: Please add: of the prostate CANCER cells after $24 \mathrm{~h}$.

Conclusions: please add: were greater than IN Du-145 and LNCaP cells.

Please write Anti-RTFscFv consistent.

\section{Introduction:}

You describe the properties of scFvs, but the property of human origin is nothing special for scFvs, MAbs could also be human and scFvs could also be of mouse origin. Of course it is and advantage if the scFv is human.

The introduction is a bit short, compared to the abstract in length. Normally the abstract is much shorter than the introduction in most of the manuscripts. You could go a bit more in detail about the way of function of the scFvs in the cancer cells (or you can mention this point in the discussion section).

\section{Methods:}

AnnexinV/FITC Assay please specify which well plate you use 6-well, 12-well, 24-well? In best case a negative control should also be included such as a non-binding scFv, to compare unspecific effects and/or a negative control cell line, not incubating the antigen/receptor etc. Make sure to write $1 \mathrm{~h}(1 \mathrm{~h}, \mathrm{hrs})$ or $10 \mathrm{mg} / \mathrm{ml}(10 \mathrm{mg} / \mathrm{ml})$ consistent throughout the manuscript. Please correct: "U-87 MGand A-17".

Please add the concentration unit (100, 200, 500, 1000 scFv/cell), e.g. nM.

Cell proliferation assay: Do you used a positive control (100\% killing) as blank value?

\section{Results:}

Selection of an anti-RTF scFv antibody: please clarify which clone was used as tested scFv. Figure 1: Please relocate $(B)$ in the figure legend.

Figure 2: Please delete title $\mathrm{X}$ and Data 1.

MTT Assay: It would be great to determine an $\mathrm{EC} \mathrm{IC}_{50}$ values for better comparison to similar acting scFvs/antibodies. Moreover, the unit of scFv/cell is not usual, in our opinion. Please write the concentration in e.g. molarity.

AnnexinV/assay: It would be great if you could also obtain and show the dot blot of the 
histograms, which is the normal way to demonstrate apoptosis. Because in the dot blots you can compare early and late apoptotic/necrotic cells as well as live cells.

It would be nice to have binding analysis of the scFv.

\section{Discussion:}

Did you have any affinity data of your new scFvs? Could you give information about the way of function of the scFvs in the cancer cells. For mAbs it could be ADCC, CDC or blocking of signaling pathways. For scFv-based Immunotoxins its receptor mediated endocytosis and the toxin acts in the cancer cells...

It would be nice to have a comparison between the toxicity of the full length mAb and the novel scFv. Are there any data available?

Binding analysis of the novel scFv to the used cell lines would be advantageous for the discussion.

Competing Interests: No competing interests were disclosed.

We confirm that we have read this submission and believe that we have an appropriate level of expertise to confirm that it is of an acceptable scientific standard, however we have significant reservations, as outlined above.

Reviewer Report 24 February 2017

https://doi.org/10.5256/f1000research.11649.r20321

(c) 2017 Alshami I. This is an open access peer review report distributed under the terms of the Creative Commons Attribution License, which permits unrestricted use, distribution, and reproduction in any medium, provided the original work is properly cited.

\section{Issam Alshami}

College of Medicine, Taibah University, Medina, Saudi Arabia

In this study, the researchers discussed well the inhibitory effects of a specific anti-RTF scFv and compared between three types of prostate cancer and two types of glioblastoma cells. The results are interesting where it has been found that the selected anti-RTF scFv antibody could be an effective new alternative for prostate cancer immunotherapy. The present study provides scientific evidence regarding that.

Data and references are update and sufficient information has been provided for replication of the experiment.

The anti-RTFscFv which is selected in this research is a novel antibody. The anti proliferative and apoptotic effects reported here make this antibody an attractive agent for immunotherapy against prostate cancer and other cancers express this antigen. As the authors mentioned the unique properties of scFv antibodies have made these small libraries ideal antibodies for targeted therapy. The anti- RTF scFv which blocks RTF will lead irregulation of extracellular and intracellular $\mathrm{pH}$ in cells and would lead to cancer cell death as shown by the authors. The in vivo study using this antibody is recommended. 
Competing Interests: No competing interests were disclosed.

I confirm that I have read this submission and believe that I have an appropriate level of expertise to confirm that it is of an acceptable scientific standard.

The benefits of publishing with F1000Research:

- Your article is published within days, with no editorial bias

- You can publish traditional articles, null/negative results, case reports, data notes and more

- The peer review process is transparent and collaborative

- Your article is indexed in PubMed after passing peer review

- Dedicated customer support at every stage

For pre-submission enquiries, contact research@f1000.com 